Editor's Note: These short reviews of recent JNeurosci articles, written exclusively by students or postdoctoral fellows, summarize the important findings of the paper and provide additional insight and commentary. If the authors of the highlighted article have written a response to the Journal Club, the response can be found by viewing the Journal Club at www.jneurosci.org. For more information on the format, review process, and purpose of Journal Club articles, please see http://jneurosci.org/content/ preparing-manuscript\#journalclub.

\title{
$\beta$-Amyloid Accumulation Slows Earlier than Expected in Preclinical Alzheimer's Disease Patients
}

\author{
${ }^{-}$Henrique Camara ${ }^{1}$ and ${ }^{-E v a n d r o ~ A . ~ D e-S o u z a ~}{ }^{2}$ \\ ${ }^{1}$ Department of Biochemistry and Tissue Biology, Institute of Biology, University of Campinas, 13083-862, Campinas, SP, Brazil and 2Institute of Medical \\ Biochemistry Leopoldo de Meis, Federal University of Rio de Janeiro, 21941-902, Rio de Janeiro, RJ, Brazil \\ Review of Leal et al.
}

\begin{abstract}
Alzheimer's disease $(\mathrm{AD})$ is the most common form of dementia, and epidemiological studies suggest that the rates of incidence will increase in the next decades (Prince et al., 2013). Clinically, AD is manifested by progressive memory loss, but the main pathophysiological hallmarks include accumulation of $\beta$-amyloid (A $\beta$ ) peptides, formation of neurofibrillary tangles containing hyperphosphorylated forms of the microtubule-associated protein tau, and synaptic failure.

Levels of $\mathrm{A} \beta$, found both as soluble oligomers or insoluble extracellular plaques, are almost invariably increased in AD patients' brains and according to the amyloid cascade hypothesis of AD pathogenesis, this accumulation is the initial pathological event leading to synaptic and cognitive dysfunction (Hardy and Higgins, 1992; Gong et al., 2003). However, this hypothesis remains somewhat controversial (Selkoe, 2013; Drachman, 2014).
\end{abstract}

Received June 23, 2018; revised Aug. 29, 2018; accepted Aug. 30, 2018.

This work is supported by CNPq (Conselho Nacional de Desenvolvimento Científico e Tecnológico, Grant 148929/2016-8) and FAPESP (Fundação de Amparo à Pesquisa do Estado de São Paulo, Grant 17/013392). We thank Laís Ferreira (Federal University of Rio de Janeiro) and Dr. Sudhir Tattikota (Harvard Medical School, Boston, MA) for helpful insights. We also thank Dr. Teresa Esch for relevant editorial comments.

The authors declare no competing financial interests.

Correspondence should be addressed to Evandro A. De-Souza, Institute of Medical Biochemistry Leopoldo de Meis, Federal University of Rio de Janeiro, 21941-902, Rio de Janeiro, RJ, Brazil. E-mail: evandro_desouza@ufrj.br.

DOI:10.1523/JNEUROSCI.1592-18.2018

Copyright $\odot 2018$ the authors $\quad 0270-6474 / 18 / 389123-03 \$ 15.00 / 0$
Indeed, the discovery that some individuals without any overt signs of dementia carry significant cerebral amyloid deposits suggests that $\mathrm{A} \beta$ plaques are not sufficient to cause $\mathrm{AD}$ (Herrup, 2015). A variation of the amyloid hypothesis accounts for this finding by proposing that soluble $\mathrm{A} \beta$ oligomers, instead of $A \beta$ plaques, are responsible for cognitive impairment in AD (Haass and Selkoe, 2007). But some authors have suggested that, although brain $\mathrm{A} \beta$ levels are elevated in $\mathrm{AD}$, this is merely a consequence of upstream problems, rather than being the cause of the disease (Drachman, 2014). Possible upstream problems include neurovascular dysfunction, unbalanced glucose homeostasis, failure in neuronal cell cycle control, and inflammation (Herrup, 2015). In support of this hypothesis, signs of neuroinflammation can be observed before $\mathrm{A} \beta$ deposition in AD mice models (Kummer et al., 2014). The failure of large clinical trials to demonstrate the effectiveness of potential disease-modifying treatments suggests that our understanding of the molecular basis of AD is incomplete (Mehta et al., 2017).

It is argued that the failure in these clinical trials stems partly from the challenge in discriminating the earliest stages of $\mathrm{AD}$, leading to the inclusion of patients whose therapeutic window has already closed. Currently, cognitively normal patients who reach a threshold of brain $\mathrm{A} \beta$ plaque load based on positron emission tomography (PET) imaging using a radioactive analog of thioflavin $\mathrm{T},{ }^{11} \mathrm{C}$ Pittsburgh Compound B (PIB), are classified as having preclinical AD (Klunk et al., 2004; Sperling et al., 2011). This classification might set thresholds too high to detect earlier stages of disease (Villeneuve et al., 2015). Identifying biomarkers that reliably discriminate the initial stages of $\mathrm{AD}$ and determining when these markers should be measured might therefore improve $\mathrm{AD}$ therapeutics.

In a recent article published in The Journal of Neuroscience, Leal et al. (2018) longitudinally evaluated $\mathrm{AD}$-associated biomarkers in 71 cognitively normal elders. Specifically, PIB and $\left[{ }^{18} \mathrm{~F}\right] \mathrm{AV}-1451$ PET brain imaging were used detect amyloid and tau plaques, respectively. The difference between the first PIB measurements (basal levels) and after an average of 4.5 years was used to define the rate of $\mathrm{A} \beta$ plaque accumulation in the brain. Surprisingly, the authors found an inverted- $U$ relationship between the $\mathrm{A} \beta$ plaque accumulation rate and $\mathrm{A} \beta$ basal levels. In other words, in the subset of this preclinical $A D$ population with a higher baseline $\mathrm{A} \beta$ burden, the $\mathrm{A} \beta$ plaque deposition rate was slowing down, suggesting saturation of $\mathrm{A} \beta$ plaque formation in the brain. Furthermore, a higher rate of $\mathrm{A} \beta$ plaque accumulation was the best predictor of future abnormal tau levels in neocortical brain regions, followed by initial levels of $A \beta$ (Leal et al., 2018). The authors 
concluded that the brains of preclinical $\mathrm{AD}$ elders have pathological modifications that predict future hallmarks of the disease.

Next, Leal et al. (2018) evaluated the correlation between brain $A \beta$ profile in preclinical $\mathrm{AD}$ patients and memory decline as assessed by verbal learning and visual reproduction tests. Correlations were analyzed in three subsets of participants, classified according to basal PIB values. Individuals with basal PIB levels $<1.07$ were classified as PIB negative, and participants with basal PIB levels $<1.30$ (including PIB-negative participants) were classified as low PIB, while the participants with basal PIB levels $>1.30$ were classified as high PIB. In PIB-negative people, neither basal levels of $A \beta$ plaques nor the rate of amyloid deposition predicted memory loss. In low-PIB participants, an increase in the amyloid deposition rate was the best predictor of cognitive decline. Finally, when including low-PIB and highPIB preclinical AD participants, basal levels of $\mathrm{A} \beta$ best predicted memory loss (Leal et al., 2018). Importantly, a parallel study reinforced the correlation between the rate of $\mathrm{A} \beta$ accumulation and memory decline in elders, strengthening the concept that the rate of amyloid accumulation is a good predictor of future $\mathrm{AD}$ pathology (Landau et al., 2018). The authors suggested that the correlation between memory decline and $\mathrm{A} \beta$ plaque accumulation in the low-PIB group indicates that disease is still spreading in individuals with the lowest $\mathrm{A} \beta$ burden. When the disease advances, reaching high basal levels of $\mathrm{A} \beta$, the initial amyloid burden better predicts future memory decline (Leal et al., 2018).

Leal et al. (2018) analyzed their findings in terms of the amyloid cascade hypothesis of $\mathrm{AD}$. Thus, they propose that the correlation between faster $A \beta$ accumulation and abnormal tau levels seen on PET imaging stems from $A \beta$ triggering cortical tau deposition. The authors also proposed that their data are consistent with the hypothesis that $\mathrm{A} \beta$ plaque increases precede tau deposition, and both precede memory impairment. Based on that interpretation, they suggest that antiamyloid therapies should be started even earlier than expected, in preclinical $\mathrm{AD}$ patients with fast accumulation of $A \beta$ plaques, otherwise the disease would be too advanced to be effective. If that is true, the inclusion of these patients in future clinical trials could elucidate the real efficacy of antiamyloid therapies and the recommended intervention window.

As noted above, however, some researchers dismiss the amyloid hypothesis, suggesting that the linear model of $A \beta$ leading to cognitive impairment is insufficient at best (Drachman, 2014). Moreover, the amyloid cascade hypotheses do not answer some questions arising from the results of the study by Leal et al. (2018). For example, why did some participants accumulate amyloid faster than others? Leal et al. (2018) observed that faster $\mathrm{A} \beta$ plaque accumulation predicts higher tau levels, but the authors measured tau only at the end of the study. An intriguing possibility is that $\mathrm{A} \beta$ "fast accumulators" actually had higher levels of tau in the beginning of the study, which caused their amyloid levels to increase. Recently, it was shown that $\mathrm{N}$-terminal fragments of tau can induce $\mathrm{A} \beta$ secretion in vitro (Bright et al., 2015), and autopsy evidence suggests that tau phosphorylation precedes $\mathrm{A} \beta$ deposition in some individuals (Jack et al., 2013). Also tau, but not $A \beta$, induced morphological abnormalities in the microvasculature of the brain and induced plasminogen activator inhibitor-1 activation in microglia in $\mathrm{AD}$ experimental models (Bennett et al., 2018), and both of these events are associated with neuronal death (Drachman, 2014). Therefore, tauopathy might be the primary driver of future cognitive decline.

Another interpretation of the data from the study by Leal et al. (2018) is that the amyloid deposition rate in patients with preclinical $\mathrm{AD}$ reflects an already toxic brain environment, which independently modulates $A \beta$ accumulation and neuronal death (Drachman, 2014). When the brain detects homeostatic imbalance, microglia are activated, culminating into neuroinflammation. Accordingly, proinflammatory signaling is activated in the brains of $\mathrm{AD}$ patients (Heneka et al., 2015). Microglia activation promotes $A \beta$ clearance by phagocytosis in mice in a process mediated by TREM2, a cell surface protein highly expressed in microglia that directly binds to $\mathrm{A} \beta$ (Zhao et al., 2018), which could explain the slowing down of $A \beta$ plaque deposition in patients with higher amyloid burden. Cross talk between angiogenesis and neuroinflammation occurs during the progression of $\mathrm{AD}$, as shown by TNF- $\alpha$-dependent microglial activation inducing blood-brain barrier disruption (Nishioku et al., 2010). Therefore, neuroinflammation could simultaneously affect levels of $A \beta$ plaques and brain functionality. In future studies, the use of PET probes for markers of immune competent cells, such as $\left({ }^{11}\right) \mathrm{C}$ PBR28 for measuring TSPO (translocator protein $18 \mathrm{kda}$ ) (Kreisl et al., 2013), and the measurement of cerebral blood flow (Roher et al., 2012) would shed light on the causality of amyloid and other $\mathrm{AD}$ hallmarks during disease progression.

A comprehensive understanding of the primary neurological changes in $\mathrm{AD}$ is essential for the development of more effective early intervention. Leal et al. (2018) provided data showing that the rate of amyloid plaque accumulation is the best predictor of future abnormal tau levels and memory decline in patients with preclinical AD with the lowest amyloid burden, demonstrating that $\mathrm{A} \beta$ measurement is suitable for predicting $\mathrm{AD}$ pathology. However, because the causality of $A \beta$ depositions remains controversial, if amyloid deposition is not the fundamental cause of $\mathrm{AD}$, clinical trials targeting amyloids are predicted to fail, even if applied in patients in the early stages of the disease. Thus, future investigations should use longitudinal approaches to measure simultaneously other AD hallmarks, such as neuroinflammation, tau alterations, and brain vascularization. This will improve our understanding of causality in $\mathrm{AD}$, paving the way for the development of alternative therapies for treating $\mathrm{AD}$.

\section{References}

Bennett RE, Robbins AB, Hu M, Cao X, Betensky RA, Clark T, Das S, Hyman BT (2018) Tau induces blood vessel abnormalities and angiogenesis-related gene expression in P301L transgenic mice and human Alzheimer's disease. Proc Natl Acad Sci U S A 115: E1289-E1298. CrossRef Medline

Bright J, Hussain S, Dang V, Wright S, Cooper B, Byun T, Ramos C, Singh A, Parry G, Stagliano N, Griswold-Prenner I (2015) Human secreted tau increases amyloid-beta production. Neurobiol Aging 36:693-709. CrossRef Medline

Drachman DA (2014) The amyloid hypothesis, time to move on: amyloid is the downstream result, not cause, of Alzheimer's disease. Alzheimers Dement 10:372-380. CrossRef Medline

Gong Y, Chang L, Viola KL, Lacor PN, Lambert MP, Finch CE, Krafft GA, Klein WL (2003) Alzheimer's disease-affected brain: presence of oligomeric A ligands (ADDLs) suggests a molecular basis for reversible memory loss. Proc Natl Acad Sci U S A 100:10417-10422. CrossRef Medline

Haass C, Selkoe DJ (2007) Soluble protein oligomers in neurodegeneration: lessons from the Alzheimer's amyloid beta-peptide. Nat Rev Mol Cell Biol 8:101-112. CrossRef Medline

Hardy JA, Higgins GA (1992) Alzheimer's disease: the amyloid cascade hypothesis. Science 256:184-185. CrossRef Medline

Heneka MT, Carson MJ, El Khoury J, Landreth GE, Brosseron F, Feinstein DL, Jacobs AH, Wyss-Coray T, Vitorica J, Ransohoff RM, Herrup K, Frautschy SA, Finsen B, Brown GC, Verkhratsky A, Yamanaka K, Koistinaho J, Latz E, Halle A, Petzold GC, et al (2015) 
Neuroinflammation in Alzheimer's disease. Lancet Neurol 14:388-405. CrossRef Medline

Herrup K (2015) The case for rejecting the amyloid cascade hypothesis. Nat Neurosci 18: 794-799. CrossRef Medline

Jack CR Jr, Knopman DS, Jagust WJ, Petersen RC, Weiner MW, Aisen PS, Shaw LM, Vemuri P, Wiste HJ, Weigand SD, Lesnick TG, Pankratz VS, Donohue MC, Trojanowski JQ (2013) Tracking pathophysiological processes in Alzheimer's disease: an updated hypothetical model of dynamic biomarkers. Lancet Neurol 12:207-216. CrossRef Medline

Klunk WE, Engler H, Nordberg A, Wang Y, Blomqvist G, Holt DP, Bergström M, Savitcheva I, Huang GF, Estrada S, Ausén B, Debnath ML, Barletta J, Price JC, Sandell J, Lopresti BJ, Wall A, Koivisto P, Antoni G, Mathis CA, et al (2004) Imaging brain amyloid in Alzheimer's disease with pittsburgh compound-B. Ann Neurol 55: 306-319. CrossRef Medline

Kreisl WC, Lyoo CH, McGwier M, Snow J, Jenko KJ, Kimura N, Corona W, Morse CL, Zoghbi SS, Pike VW, McMahon FJ, Turner RS, Innis RB (2013) In vivo radioligand binding to translocator protein correlates with severity of Alzheimer's disease. Brain 136:2228-2238. CrossRef Medline

Kummer MP, Hammerschmidt T, Martinez A, Terwel D, Eichele G, Witten A, Figura S, Stoll M, Schwartz S, Pape HC, Schultze JL, Weinshenker D, Heneka MT, Urban I (2014) Ear2 deletion causes early memory and learning deficits in APP/PS1 mice. J Neurosci 34:88458854. CrossRef Medline

Landau SM, Horng A, Jagust WJ (2018) Memory decline accompanies subthreshold amyloid accumulation. Neurology 90:e1452e1460. CrossRef Medline

Leal SL, Lockhart SN, Maass A, Bell RK, Jagust WJ (2018) Subthreshold amyloid predicts tau deposition in aging. J Neurosci 38:4482-4489. CrossRef Medline

Mehta D, Jackson R, Paul G, Shi J, Sabbagh M (2017) Why do trials for Alzheimer's disease drugs keep failing? A discontinued drug perspective for 2010-2015. Expert Opin Investig Drugs 26:735-739. CrossRef Medline

Nishioku T, Matsumoto J, Dohgu S, Sumi N, Miyao K, Takata F, Shuto H, Yamauchi A, Kataoka Y (2010) Tumor necrosis factor-alpha mediates the blood-brain barrier dysfunction induced by activated microglia in mouse brain microvascular endothelial cells. J Pharmacol Sci 112:251254. CrossRef Medline

Prince M, Bryce R, Albanese E, Wimo A, Ribeiro W, Ferri CP (2013) The global prevalence of dementia: a systematic review and metaanalysis. Alzheimers Dement 9:63-75.e2. CrossRef Medline

Roher AE, Debbins JP, Malek-Ahmadi M, Chen K, Pipe JG, Maze S, Belden C, Maarouf CL, Thiyyagura $\mathrm{P}$, Mo H, Hunter JM, Kokjohn TA, Walker DG, Kruchowsky JC, Belohlavek M, Sabbagh MN, Beach TG (2012) Cerebral bl- ood flow in Alzheimer's disease. Vasc Health Risk Manag 8:599-611. CrossRef Medline

Selkoe DJ (2013) The therapeutics of Alzheimer's disease: where we stand and where we are heading. Ann Neurol 74:328-336. CrossRef Medline

Sperling RA, Aisen PS, Beckett LA, Bennett DA, Craft S, Fagan AM, Iwatsubo T, Jack CR Jr, Kaye J, Montine TJ, Park DC, Reiman EM, Rowe CC, Siemers E, Stern Y, Yaffe K, Carrillo MC, Thies B, Morrison-Bogorad M, Wagster MV, et al. (2011) Toward defining the preclinical stages of Alzheimer's disease: recommendations from the national institute on aging-Alzheimer's association workgroups on diagnostic guidelines for Alzheimer's disease. Alzheimers Dement 7:280-292. CrossRef Medline

Villeneuve S, Rabinovici GD, Cohn-Sheehy BI, Madison C, Ayakta N, Ghosh PM, La Joie R, Arthur-Bentil SK, Vogel JW, Marks SM, Lehmann M, Rosen HJ, Reed B, Olichney J, Boxer AL, Miller BL, Borys E, Jin LW, Huang EJ, Grinberg LT, et al. (2015) Existing pittsburgh compound-B positron emission tomography thresholds are too high: statistical and pathological evaluation. Brain 138:20202033. CrossRef Medline

Zhao Y, Wu X, Li X, Jiang LL, Gui X, Liu Y, Sun Y, Zhu B, Piña-Crespo JC, Zhang $M$, Zhang $\mathrm{N}$, Chen X, Bu G, An Z, Huang TY, Xu H (2018) TREM2 is a receptor for $\beta$-amyloid that mediates microglial function. Neuron 97:10231031.e7. CrossRef Medline 